\title{
Peningkatan Hasil Belajar IPA melalui Pembelajaran CTL Berbantu Media Audiovisual pada Siswa Kelas IV SD Negeri Karangbandung 02
}

\author{
Meidian Kusumahati \\ SD Negeri Karangbandung 02 \\ meidiankusumahati@gmail.com
}

\section{Article History}

received $3 / 12 / 2020$

\begin{abstract}
The purpose of this Classroom Action Research is to improve learning outcomes of science lessons on the theme Caring for living things in fourth grade students of SD Negeri Karangbandung 02, Keanggungan District, Brebes Regency using the CTL model assisted by audiovisual media. In this model, classroom action research is carried out through four stages, namely planning, action implementation, observation, and reflection and is carried out in three cycles. From this classroom action research, the results obtained in the first cycle that the average student score was 70.13 with a completeness percentage of $54.17 \%$. In the second cycle it increased to 79.15 with a completeness percentage of $65.7 \%$. In the third cycle the average score of students became 87.08 with a completeness percentage of $91.6 \%$. Based on the data obtained, it can be concluded that the use of the CTL model with the aid of audiovisual media can improve the learning outcomes of the science theme Caring for Living Creatures in fourth grade students of SD Negeri Karangbandung 02 Ketanggungan District, Brebes Regency.
\end{abstract}

Keywords: learning outcomes,science, CTL, audiovisual

\begin{abstract}
Abstrak
Tujuan Penelitian Tindakan Kelas ini adalah meningkatan hasil belajar muatan pelajaran IPA pada tema Peduli terhadap makhluk hidup pada siswa kelas IV SD Negeri Karangbandung 02 Kecamatan Ketanggungan Kabupaten Brebes menggunakan model CTL berbantuan media audiovisual. Dalam model ini, penelitian Tindakan kelas ini dilaksanakan melalui empat tahap yaitu perencanaan, pelaksanaan tindakan, observasi, dan refleksi serta dilakukan dalam tiga siklus. Dari penelitian tindakan kelas ini diperoleh hasil pada siklus I rata-rata nilai siswa adalah 70,13 dengan persentase ketuntasan sebesar $54,17 \%$. Pada siklus II meningkat menjadi 79,15 dengan persentase ketuntasan $65,7 \%$.Pada siklus III nilai rata-rata siswa menjadi 87,08 dengan persentase ketuntasan sebesar $91,6 \%$. Berdasarkan data yang diperoleh, dapat disimpulkan bahwa penggunaan model CTL berbantuan media audiovisual dapat meningkatkan hasil belajar IPA tema Peduli terhadap Makhluk Hidup pada siswa kelas IV SD Negeri Karangbandung 02 Kecamatan Ketanggungan Kabupaten Brebes.
\end{abstract}

Kata kunci: hasil belajar, IPA, CTL, audiovisual

Social, Humanities, and Education Studies (SHEs): Conference Series https://jurnal.uns.ac.id/shes

p-ISSN 2620-9284

e-ISSN 2620-9292 


\section{PENDAHULUAN}

Menurut Peraturan Menteri Pendidikan dan Kebudayaan no 57 tahun 2014 tentang tujuan kurikulum SD bahwa Kurikulum 2013 bertujuan untuk mempersiapkan manusia Indonesia agar memiliki kemampuan hidup sebagai pribadi dan warga negara yang beriman, produktif, kreatif, inovatif, dan afektif serta mampu berkontribusi pada kehidupan bermasyarakat, berbangsa, bernegara, dan peradaban dunia.

Salah satu mata pelajaran yang diajarkan di sekolah dasar pada kurikulum 2013 adalah mata pelajaran IPA (IImu Pengetahuan Alam). IPA memiliki karakteristik yang tidak sama dengan mata pelajaran yang lain. Sehingga dalam mengajarkannya dibutuhkan beberapa hal diantaranya metode, media, perangkat pembelajaran dan keterampilan dalam mengajar yang disesuaikan dengan mata pelajaran IPA khususnya di sekolah dasar (Farida 2016: 33) Pembelajaran IPA dapat diintegrasikan dengan pembelajaran yang lain seperti pembelajaran PPKn dan pembelajaran bahasa Indonesia melalui penggabungan kompetensi dasar tiap-tiap mata pelajaran. Penggabungan mata pelajaran IPA dengan mata pelajaran lain terlebih lagi dengan mata pelajaran yang membahas tentang ilmu-ilmu sosial sangatlah relevan, karena pembelajaran IPA adalah pembelajaran yang mewujudkan pengetahuan, pemahaman, dan kemampuan analisis terhadap kondisi sosial masyarakat dalam memasuki kehidupan bermasyarakat yang dinamis.

Dalam menyelenggarakan pembelajaran pada muatan IPA, peran guru adalah sebagai motivator, mediator dan fasilitator. Namun ada kecenderungan pemahaman IPA adalah pelajaran hafalan sehingga pembelajaran cenderung menggunakan metode ceramah, menekankan aktivitas guru, bukan aktivitas siswa, kurang variatif, siswa lebih banyak mencatat daripada aktif dan mandiri belajar. Penggunaan strategi dan media yang monoton mengakibatkan motivasi belajar siswa rendah, kurang aktif dalam pembelajaran yang berujung hasil belajar rendah.

Menurut Oemar Hamalik (dalam Rusman 2012: 123) mengatakan: "Hasil belajar itu dapat terlihat dari terjadinya perubahan dari persepsi dan perilaku, termasuk juga perbaikan perilaku". Hasil belajar terbagi kedalam beberapa jenis, Benyamin Bloom (dalam Nana Sudjana, 2013: 22-23) mengkasifikasikan jenis-jenis hasil belajar menjadi tiga ranah, yaitu : ranah kognitif, afektif dan psikomotoris. Ranah kognitif berkenaan dengan hasil belajar intelektual, ranah afektif berkenaan dengan sikap dan ranah psikomotoris berkenaan dengan hasil belajar keterampilan.

Berdasarkan refleksi yang dilaksanakan peneliti dapat diambil simpulan bahwa pembelajaran muatan IPA kelas IV masih belum memenuhi kriteria. Pembelajaran cenderung berpusat pada guru. Selain itu guru kurang memberikan pengalaman serta konteks keseharian siswa sehingga sebagian besar siswa tidak aktif dalam pembelajaran. Strategi belajar dan media yang dimanfaatkan juga belum menarik perhatian siswa secara menyeluruh. Akibatnya, sebagian besar hasil belajar IPA siswa kelas IV pada semester 1 tahun pelajaran 2019/2020 masih dibawah KKM yaitu 70.

Permasalahan yang terjadi didukung dengan data hasil belajar siswa, sebanyak 34 siswa kelas IV SD Negeri Karangbandung 02 , terdapat siswa yang belum memahami sepenuhnya materi dalam pembelajaran IPA tema "Peduli Terhadap Makhluk Hidup" KD 3.1 ditunjukkan dengan data 19 siswa (64\%) memperoleh nilai di bawah KKM . Sementara itu, 11 siswa (36\%) memperoleh nilai di atas KKM.

Alternatif pemecahan masalah guna meningkatkan kualitas pembelajaran tema "Peduli Terhadap makhluk Hidup" pada muatan IPA kelas IV adalah dengan menerapkan pendekatan saintifik dengan pembelajaran CTL berbantuan media audiovisual. Kolaborasi antara pendekatan pembelajaran dan media tersebut bertujuan untuk memudahkan siswa dalam memahami materi IPA melalui pembelajaran yang menyenangkan dan bermakna. inti dari pembelajaran kontekstual adalah keterkaitan setiap materi atau topik pembelajaran dengan kehidupan nyata. Untuk mengaitkannya bisa dilakukan dengan cara, selain karena memang materi yang dipelajari secara 
langsung terkait dengan kondisi faktual juga bisa disiasati dengan pemberian ilustrasi atau contoh, sumber belajar, media dan lain sebagainya, yang memang baik secara langsung maupun tidak langsung diupayakan terkait atau ada hubunganya dengan pengalaman hidup nyata. Media audiovisual merupakan media yang penyerapan materinya melalui pandangan dan pendengaran sehingga membangun kondisi yang dapat membuat siswa mampu memperoleh pengetahuan, keterampilan, atau sikap.

Adapun penelitian yang mendukung pemecahan masalah yang ditetapkan adalah penelitian yang dilakukan oleh Ruiyati, dkk dalam penelitiannya yang berjudul "Meningkatkan Hasil Belajar Siswa pada Mata Pelajaran IPA Melalui Pembelajaran CTL (Contextual Teaching and Learning) di Kelas IV SD Inpres 3 Terpencil Baina'a." Hasil penelitian siklus I presentase daya serap klasikal 79,54\% dan ketuntasan belajar klasikal 63,64\%. Hasil belajar siklus II seluruh siswa dinyatakan lulus $100 \%$ dengan presentase daya serap klasikal 87,27\%. Dengan demikian dapat dikatakan bahwa pendekatan CTL dapat meningkatkan hasil belajar siswa kelas IV SD Inpres 3 Terpencil Baina'a.

Penerapan Model Pembelajaran Contextual Teaching and Learning untuk Meningkatkan Aktivitas dan Hasil Belajar IPA Siswa Kelas V Sd Negeri 060885 Medan. Hasil penelitian penerapan pembelajaran CTL: 1) dapat meningkatkan hasil belajar siswa dengan peningkatan sebesar $58,17 \%$, 2) penerapan pembelajaran CTL dapat meningkatkan aktivitas belajar siswa sebesar 19,72\%.

Dari alternatif pemecahan masalah yang ditetapkan tersebut, diharapkan dapat meningkatkan kualitaas pembelajaran IPA yang ditandai dengan meningkatknya keterampilan guru, aktivitas siswa, dan hasil belajar siswa. Melalui pendekatan CTL berbantuan media audiovisual, guru akan tertantang untuk menciptakan suasana belajar yang aktif, menyenangkan, dan bermakna. Siswa juga dapat belajar sekaligus menyalurkan minat dan naluri bermainnya dalam pembelajaran. Dengan demikian, pembelajaran akan menjadi pembelajaran yang sarat dengan makna.

Penelitian ini dilakukan dengan tujuan untuk meningkatkan kualitas pembelajaran tema "Peduli Terhadap Makhluk Hidup" pada muatan IPA siswa kelas IV SD Negeri Karangbandung 02. Hasil penelitian ini diharapkan akan memberikan manfaat berupa sumbangan positif bagi pendidikan di Indonesia khususnya pada pengembangan inovasi pembelajaran IPA di SD.

\section{METODE}

Pada penelitian ini menggunakan desain penelitian tindakan kelas. Menurut pendapat Suharsimi (2011:3) penelitian tindakan kelas merupakan suatu pencermatan terhadap kegiatan belajar berupa sebuah tindakan, yang sengaja diumculkan dan terjadi dalam sebuah kelas secara bersama. Penelitian tindakan kelas itu sendiri mengharuskan guru untuk selalu berusaha melakukan tindakan pembaharuan (inovasi) dalam proses belajar mengajar. Adapun model PTK yang diterapkan adalah model Kemmis\&McTaggart. Model ini merupakan pengembangan dari konsep dasar yang dikemukakan oleh Kurt. D Lewin. Dalam model ini, PTK dilaksanakan melalui 4 tahap yaitu perencanaan, pelaksanaan tindakan, observasi, dan refleksi dimana pelaksanaannya berkelanjutan ke siklus-siklus berikutnya. Penelitian dengan menerapkan pendekatan CTL berbantuan media audiovisual ini dilaksanakan dalam tiga siklus dengan masing-masing siklus terdiri dari satu pertemuan. Subjek dalam penelitian ini adalah siswa kelas IV sebanyak 34 siswa yang terdiri dari 12 siswa lakilaki dan 22 siswa perempuan, penelitian ini dilaksanakan di SD Negeri Karangbandung 02. Teknik pengumpulan data pada penelitian ini adalah Kuantitatif. Data kuantitatif dalam penelitian ini diperoleh dari nilai siswa hasil pembelajaran muatan IPA tema Peduli Terhadap Makhluk Hidup dengan model CTL dan media audio visual, menggunakan teknik analisis deskriptif. dengan menentukan mean atau rerata, skor terendah, dan skor tertinggi terhadap nilai yang diperoleh siswa, serta menentukan ketuntasan belajar klasikal. 


\section{HASIL DAN PEMBAHASAN}

Penelitian tindakan kelas "Peningkatan Hasil Belajar IPA melalui model CTL dengan berbatuan media audiovisual pada siswa kelas IV SD Negeri Karangbandung 02" ini mengkaji efektivitas dari model CTL dan media audiovisual untuk meningkatkan hasil belajar siswa. Hasil penelitian pada siklus I, II, dan III akan disajikan dalam paparan berikut ini.

Pada siklus I, berdasarkan hasil analisis data evaluasi siswa dalam bentuk pilihan ganda pada pembelajaran muatan IPA tema Peduli Terhadap Makhluk Hidup dengan model CTL berbantuan media audiovisual pada siswa kelas IV, diperoleh data bahwa hasil belajar siswa pada siklus I belum memenuhi kriteria keberhasilan dengan persentase ketuntasan sebesar $54,17 \%$. Meskipun demikian, nilai rata-rata siswa sudah memenuhi KKM yaitu 70,13. Hasil tersebut diperoleh berdasarkan proses pembelajaran yang dilaksanakan melalui sinergi antara keterampilan guru dan aktivitas siswa. Oleh karena keterampilan guru dan aktivitas siswa masih belum memenuhi kriteria keberhasilan, maka dapat dipastikan hasil belajar siswa pun belum baik. Karena hasil belajar merupakan perubahan perilaku yang diperoleh peserta didik setelah mengalami kegiatan belajar (Rifa'i, 2010:85).

Setelah melalui beberapa perbaikan, pada siklus II diperoleh hasil 65,7\% atau sebanyak 16 siswa dinyatakan tuntas. Sedangkan 33.3\% atau sebanyak 8 siswa dinyatakan tidak tuntas dalam belajar. Rata-rata nilai siswa adlah 79,15 dengan nilai tertinggi 100 , dan nilai terendah 66,7 . Siswa yang mendapatkan nilai 66,7 sebanyak 8 siswa atau $33,3 \%$, siswa yang mendapatkan nilai antara 83,3 sebanyak 14 siswa atau $58,3 \%$, dan siswa yang mendapatkan nilai 100 sebanyak 2 siswa atau $8,3 \%$. Nilai yang sering muncul adalah antara 83,3. Dengan demikian dapat disimpulkan bahwa hasil nilai pengetahuan siswa belum mencapai indikator keberhasilan yaitu ketuntasan belajar siswa sebanyak $80 \%$. Pada siklus II mengalami peningkatan dengan persentase $65,7 \%$ dan nilai rata-rata siswa 79,15. Dengan demikian dapat ditarik simpulan bahwa dalam pembelajaran berpusat pada siswa sekalipun, jika keterampilan guru dalam pembelajaran sudah baik, maka respon atau aktivitas siswa pun menjadi semakin baik dan hasil belajar akan meningkat. Sebagaimana dinyatakan Dananjaya, (2010:19) bahwa pembelajaran merupakan suatu konsep pendidikan yang lahir dari perubahan paradigma lama yaitu pengajaran, sehingga dominasi guru harus diubah menjadi siswa aktif mengembangkan potensi dirinya dalam suasana belajar yang menyenangkan, interaktif, inspiratif, menantang, bebas berprakarsa dan kreatif.

Pada siklus III, setelah dilakukan evaluasi diperoleh hasil $91,6 \%$ atau sebanyak 21 siswa dinyatakan tuntas. Sedangkan $8,3 \%$ atau sebanyak 3 siswa dinyatakan tidak tuntas dalam belajar. Rata-rata nilai siswa adlah 87,08 dengan nilai tertinggi 100 , dan nilai terendah 60 . Siswa yang mendapatkan nilai 60 sebanyak 3 siswa atau $12 \%$, siswa yang mendapatkan nilai antara 80 sebanyak 5 siswa atau $20,8 \%$, siswa yang mendapat nilai 90 sebanyak 9 siswa atau $37,5 \%$ dan siswa yang mendapatkan nilai 100 sebanyak 7 siswa atau $28 \%$. Nilai yang sering muncul adalah antara 90 . Dengan demikian dapat disimpulkan bahwa hasil nilai pengetahuan siswa sudah mencapai indikator keberhasilan yaitu ketuntasan belajar siswa sebanyak $80 \%$. Pada siklus III mengalami peningkatan kembali dengan nilai rata-rata siswa menjadi 87,08 dan persentase ketuntasan sebesar $91,6 \%$. Persentase ketuntasan tersebut sudah memenuhi kriteria keberhasilan hasil yang ditentukan yaitu $>80 \%$.

Selama penelitian, hasil belajar siswa selalu meningkat di setiap siklusnya. Pada siklus I evaluasi memperoleh hasil yang masih dibawah kriteria keberhasilan yang ditargetkan. Kemudian pada siklus II dan III hasil belajar meningkat kembali dan telah mencapai kriteria keberhasilan.

Adapun peningkatannya disajikan dalam diagram berikut: 


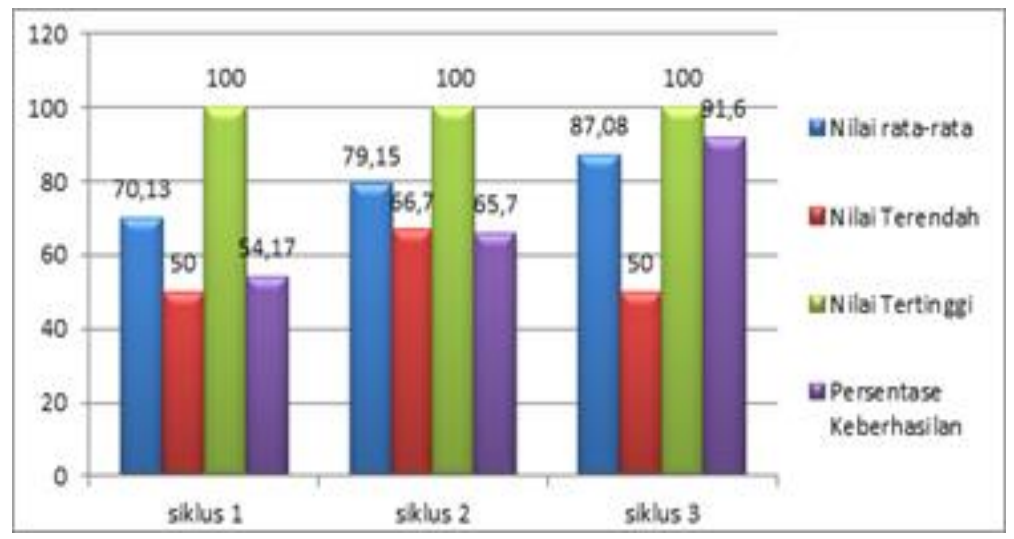

Gambar 1. Hasil Belajar Siswa selama tiga siklus

Berdasarkan hasil siklus I,II, dan III dapat ditarik kesimpulan bahwa model CTL dan media audiovisual dapat meningkatkan hasil belajar siswa. Hal ini sejalan dengan pendapat Blanchard (Komalasari, 2010:6) mengemukakan bahwa pembelajaran kontekstual merupakan konsep belajar dan mengajar yang membantu guru mengaitkan antara materi yang diajarkan dengan situasi dunia nyata siswa dan mendorong siswa membuat hubungan antara pengetahuan yang dimilikinya dengan penerapannya dalam kehidupan mereka sebagai anggota keluarganya, warga negara, dan pekerja. Selain itu, menurut pendapat Ishak Abdullah (2013: 82) Media audiovisual pada hakikatnya adalah suatu representasi (penyajian) realitas, terutama melalui pengindraan, penglihatan dan pendengaran yang bertujuan untuk mempertunjukan pengalaman-pengalaman pendidikan yang nyata kepada siswa. Cara ini dianggap lebih tepat, cepat, dan mudah dibandingkan dengan melalui pembicaraan, pemikiran, dan cerita mengenai pengalaman pendidikan.

\section{SIMPULAN}

Berdasarkan hasil penelitian mengenai penerapan model CTL berbantuan media audiovisual pada siswa kelas IV SD Negeri Karangbandung 02, peneliti membuat simpulan bahwa Penerapan model CTL berbantuan media audiovisual dapat meningkatkan pengetahuan siswa dalam pembelajaran tema "Peduli Terhadap Makhluk Hidup" kelas IV SD Negeri Karangbandung 02. Hal ini dibuktikan dengan hasil penelitian yaitu pada siklus I rata-rata nilai siswa adalah 70,13 dengan persentase ketuntasan sebesar $54,17 \%$. Kemudian pada siklus II meningkat ditunjukkan oleh nilai rata-rata siswa menjadi 79,15 dengan persentase ketuntasan $65,7 \%$. Dan pada siklus III mengalami peningkatan kembali ditunjukkan dengan nilai rata-rata siswa menjadi 87,08 dengan persentase ketuntasan sebesar 91,6\%. Untuk meningkatkan (1) Sebaiknya guru menerapkan keterampilan dasar mengajar secara optimal dan kreatif dalam merancang pembelajaran yang menyenangkan dan bermakna pada mata pelajaran IPA salah satunya dengan menerapkan model CTL berbantuan media audiovisual. (2) Sebaiknya guru memotivasi dan mengarahkan siswa untuk belajar dengan aktif, antusias, dan kreatif menyalurkan bakat dan potensinya dalam pembelajaran IPA sehingga hasil belajar akan terus meningkat lebih baik.

\section{DAFTAR PUSTAKA}

Abdullah, Ishak \& Darmawan, Deni. 2013. Teknologi Pendidikan. Bandung: PT. Remaja Rosdakarya.

Arikunto, Suharsimi, dkk. (2011). Penelitian Tindakan Kelas. Jakarta: PT Bumi Aksara. 
Kementrian Pendidikan dan Kebudayaan RI. (2014). Peraturan Mendiknas tentang kurikulum SD (Permendiknas Nomor 57 tahun 2014). Jakarta: Penulis.

Komalasari, Kokom. (2010). Pembelajaran Kontekstual. Bandung: PT. Refika Aditama

Kumala, Farida Nur. (2016). Pembelajaran IPA Sekolah Dasar. Malang: Ediide Indografika

Nana Sudjana. (2013). Dasar-Dasar Proses Belajar Mengajar. Bandung: Sinar Baru Algesindo

Rifai'i dan Anni. 2010. Psikologi Pendidikan. Brebes: UNNES Press

Ruiyati, dkk. 2013. Meningkatkan Hasil Belajar Siswa pada Mata Pelajaran IPA Melalui Model CTL (Contextual Teaching and Learning) di Kelas IV SD Inpres 3 Terpencil Baina'a. Jurnal Pendidikan Universitas Tadulako. Volume 4 No. 6: (Hal. 212-223) http://jurnal.untad.ac.id/jurnal/

Rusman. (2012). Belajar dan Pembelajaran Berbasis Komputer. Bandung: Alfabetha 